DOI: $\underline{10.34305 / g e m i c . v 1 i 1.310}$

\title{
THE EFFECT OF MOTHER'S KNOWLEDGE AND PROFESSION ON THE SUCCESS OF EXCLUSIVE BREASTFEEDING IN THE WORKING AREA OF PUSKESMAS SURANENGGALA, CIREBON DISTRICT, YEAR 2021
}

\author{
Lisnawati, Siti Soleha \\ Poltekkes Kemenkes Tasikmalaya \\ bidan_lisna85@yahoo.com
}

\begin{abstract}
Introduction : According to the coverage of exclusive breastfeeding in regencies and cities in West Java, the lowest coverage of exclusive breastfeeding for infants 0-6 months is $20.34 \%$ in Bandung Regency, while the highest coverage is exclusive breastfeeding in Tasikmalaya Regency $113.11 \%$. Meanwhile, the coverage of exclusive breastfeeding in Cirebon Regency is $32.79 \%$, with the fifth lowest in regencies and cities in West Java.

Methods: Analytical research with 1: 1 case control technique, the population in this study were mothers who had babies aged 6-12 months with a population of 269 people. The samples used in this study were 30 in the case group and 30 in the control group. Collecting data by dividing the case group and the control group, namely the proportional random sampling technique in the control group and the total sampling in the case group. The instrument used was a questionnaire. The data analysis of this research used univariate and bivariate.

Results: In the univariate test results on the knowledge variable, it was found that mothers in the majority of cases group had good knowledge, namely 25 mothers $(83.4 \%)$ and mothers in the control group, the majority had good knowledge, namely 13 mothers (43.3\%). While for the variable of maternal occupation the case group did not work as much as 26 (86.7\%) and the control group did not work as much as 27 (90\%). For bivariate analysis, the results of statistical tests using the chi-square test between the variables of maternal knowledge about breastfeeding and the exclusive breastfeeding variable obtained a $\mathrm{p}$ value value of $0.003(<0.05)$, the OR value in the comparator was good against $0.260(0.66-1.028)$, whereas in the comparison group it was good to less $4,500(0.418-49.077)$. In the work variable, the $\mathrm{p}$ value is 1.00 (> 0.05) with an OR value of $0.722(0.147-3.545)$. Mother's knowledge has a 4.5 -fold effect on the success of exclusive breastfeeding, while for work there is no effect on the success of exclusive breastfeeding.
\end{abstract}

Keywords: knowledge, work and exclusive breastfeeding. 


\section{Introduction}

Infant and neonatal mortality rates in 2018 were mostly caused by, 28\% asphyxia, 3\% sepsis, 40\% LBW, 12\% abnormalities, $17 \%$ others, in which there was jaundice and in post neonatal the cause of death was diarrhea, $13 \%$. , pneumonia $21 \%$, gastrointestinal infections $4 \%$, malaria $1 \%$, neurological disorders $2 \%$, and others $59 \%$. One of the SDGs targets that will be achieved is to reduce the mortality rate for children by reducing the IMR to $12 / 1000$ live births in 2030. The infant mortality rate due to gastrointestinal infections and diarrhea is also quite high. Breast milk contains immunological substances to protect babies from infection. Breastfed babies are also at lower risk of developing infections or digestive disorders, allergies, asthma, diabetes, obesity and cancer in childhood. (Anggraeni, 2016).

Exclusive breastfeeding has benefits according to the needs of babies that have never been found in formula milk, nutritional content, among others, protein $8.5 \%$, fat $2.5 \%$, carbohydrates $3.5 \%$, salt and minerals $0.4 \%$, water $85,1 \%$. Meanwhile, the increasing the age of the baby, the higher the protein content and the lower the fat content and the higher the carbohydrate content. The content in breast milk that has been adjusted to the needs of the baby is not like the content of formula milk, which is the same for any age and the amount is the same and is difficult for the baby's body to absorb (Mufdlilah, 2017).

According to the West Java Provincial Health Office, in 2017, there were 3077 babies who died. Meanwhile, based on recording and reporting in the profile of West Java in 2018, there were 3,083 cases of infants dying, increasing from 2017. The proportion of infant deaths in 2017 was 3.4 / 1000 live births, decreased by 0.53 points compared to 2016 of 3,93/1000 live births. The proportion of infant mortality in 2018 was 3.4 / 1000 live births or 3.083 cases. The proportion of infant mortality from 0-28 days (neonatal) was $84.63 \%$ or $3.32 / 1000$ live births.

According to the coverage of exclusive breastfeeding in regencies and cities in West Java, the lowest coverage of exclusive breastfeeding for babies 0-6 months is $20.34 \%$ in Bandung Regency, while the highest coverage is exclusive breastfeeding in Tasikmalaya Regency $113.11 \%$. While the coverage of exclusive breastfeeding in Cirebon Regency is 
$32.79 \%$ with the fifth lowest in regencies and cities in West Java. Various factors behind the low coverage of exclusive breast feeding, several studies have found that predisposing factors including age, education level, occupation, and knowledge have a relationship to exclusive breastfeeding (Hilala, 2013). Exclusive breast feeding is related to maternal knowledge. Sufficient knowledge of mothers about exclusive breastfeeding which motivates mothers to provide exclusive breastfeeding. The results of other studies show that mothers who work and do not provide exclusive breastfeeding are $66.7 \%$ and mothers with less knowledge do not exclusively breastfeed at $94.4 \%$. (Astuti, 2013).

According to research Bahriyah, Putri \& Jaelani, (2017) the results of this study prove that the knowledge of mothers who have high knowledge about exclusive breastfeeding and about the benefits of exclusive breastfeeding so that they end up trying to provide exclusive breastfeeding, most working mothers object to exclusive breastfeeding because of difficulties in dividing their time for providing exclusive breastfeeding and lack of knowledge about how to express and store exclusive breastfeeding.
According to research Triseptinora, (2018) The results of the analysis of the relationship between mother's work and exclusive breast feeding show that of the 29 respondents who did not work there were $14(30.4 \%)$ mothers who did not provide exclusive breastfeeding. Meanwhile, there are $15 \quad(75 \%)$ mothers who work exclusively breastfeeding who do not provide exclusive breastfeeding. The results of statistical tests obtained $\mathrm{p}$-value $=0.002$ (p-value <0.05), it can be concluded that there is a significant relationship between work status and exclusive breastfeeding. With an OR (odd ratio) of 6.8 (2.08422.56), this means that working mothers have 6 to 7 times the risk of not giving exclusive breast feeding compared to mothers who do not work.

Based on the results of the Cirebon District Health Office report in 2018, coverage of exclusive breastfeeding for babies aged 6 months in all Puskesmas in Cirebon Regency. The attainment of exclusive breastfeeding in the district is $69.1 \%$, of the total number of babies of 36,251 people who are given exclusive breast feeding is only 25,045 people. The highest achievement of exclusive breast feeding was $200.6 \%$ in the sub-district of the Bunder Health Center, while the lowest 
was in the Jamblang sub-district, the working area of the Wangunharja Community Health Center, namely $11.3 \%$. The Suranenggala Puskesmas has the 4th lowest breastfeeding coverage, namely $21.3 \%$

Based on the results of a preliminary survey in the work area of the Suranenggala Health Center which was conducted with a breastfeeding knowledge questionnaire containing 24 questions (taken from Ina Masripah's research entitled the relationship between maternal knowledge and exclusive breastfeeding in the work area of Puskesmas Plumbon, Cirebon Regency 2016). In 10 mothers who had babies aged 6-12 months, it was found that 8 people did not provide exclusive breast feeding, but 9 of them had a good level of knowledge but one person had a sufficient level of knowledge. Of the 10 mothers who have babies 6-12 months, only 3 work, the majority of others do not work.

\section{Method}

The design in this study uses analytical techniques with a case control approach (1:1). The case group is a group of babies who are given exclusive breast feeding, the control group is those who are not exclusively breastfed. This research was conducted in the working area of the Suranenggala Community Health Center. Conducted in February - April 2021. In the village (Purwawinangun, Keraton, Surakarta, Karangreja, Suranenggala Kidul, Suranenggala Lor, Suranenggala Kulon, Suranenggala).

The population in this study were mothers who had babies aged 6-12 months with a total of 269 in the work area of the Suranenggala Health Center in 2021. Sampling in the case group used total sampling by taking all samples from 1 February 2021 - 28 February as many as 30 samples. As for the control group, it was carried out using a proportional random sampling technique. In this study, including the inclusion criteria are: Willing to be research respondents and filling out a questionnaire and mothers who have children aged 6-12 months.

The data collection instrument used in this study was a questionnaire from Ina Masripah's research entitled the relationship between maternal knowledge and exclusive breastfeeding in the work area of the Plumbon Public Health Center, Cirebon Regency 2016, which had been tested for validity, with a cronbach's alpha value $=$ 0.884. The questionnaire contained 24 closed questions, the types of questions 
about mother's knowledge of exclusive breast feeding and the myths of exclusive breastfeeding. Bivariate data analysis using the chi square technique.

Data collection activities are carried out directly in accordance with the permission from the puskesmas. Data collection also followed health protocols where researchers conducted rapid antigen tests and conducted research using gowns,

a. Knowledge gloves, masks, hand sanitizers, and applied distance maintenance.

\section{Results}

To find out the bivariate analysis in the knowledge group because it uses a $3 \times 2$ table, the $\mathrm{p}$ value uses chi square and for the OR value uses simple regression.

Table 1. The Relationship of Mother's Knowledge of the Success of Exclusive Breastfeeding (Chi-Square)

\begin{tabular}{lccccc}
\hline Variable & \multicolumn{2}{c}{ Case } & \multicolumn{2}{c}{ Control } & \multirow{2}{*}{$\boldsymbol{P}$ Value } \\
\cline { 2 - 5 } Knowledge & F & \% & F & \% & \\
\hline 1. Good & 25 & 83,4 & 13 & 43,3 & \\
2. Enough & 1 & 3,3 & 9 & 30 & 0,003 \\
3. less & 4 & 13,3 & 8 & 26,7 & \\
Total & 30 & 100 & 30 & 100 & \\
\hline
\end{tabular}

Table 2. The Relationship of Mother's Knowledge of the Success of Exclusive Breastfeeding (simple regression test)

\begin{tabular}{lcccc}
\hline \multicolumn{1}{c}{ Knowledge } & $\boldsymbol{P}$ Value & OR $($ CI 95\%) & Lower & Upper \\
\hline Good-Enough & 0,55 & 0,260 & 0,66 & 1,028 \\
Good-Less & 0,217 & 4,500 & 0,418 & 49,077 \\
\hline
\end{tabular}

Based on the results of statistical tests with the chi-square test between the variables of maternal knowledge about breastfeeding and the exclusive breastfeeding variable, the $\mathrm{p}$ value value was $0.003(<0.05)$, which means that there is a relationship between maternal knowledge and the success of exclusive breastfeeding. The OR value in the comparator is good against $0.260(0.66-$ 
b. Profession

Table 3. The Relationship of Mother's Work to the Success of Exclusive Breastfeeding

\begin{tabular}{|c|c|c|c|c|c|c|}
\hline \multirow{3}{*}{ Mother's Work } & \multicolumn{4}{|c|}{ Exclusive Breastfeeding } & \multirow{3}{*}{$P$ Value } & \multirow{3}{*}{ OR $(95 \% \mathrm{CI})$} \\
\hline & \multicolumn{2}{|c|}{ Case } & \multicolumn{2}{|c|}{ Control } & & \\
\hline & $\mathbf{F}$ & $\%$ & $\mathbf{F}$ & $\%$ & & \\
\hline Does Not Work & 26 & 86,7 & 27 & 90 & \multirow{3}{*}{1.00} & \multirow{3}{*}{$\begin{array}{c}0,722(0,147- \\
3,545)\end{array}$} \\
\hline Work & 4 & 13,3 & 3 & 10 & & \\
\hline Total & 30 & 100 & 30 & 100 & & \\
\hline
\end{tabular}

statistical tests with the chi-square test between the variables of maternal occupation and the success of exclusive breastfeeding, obtained a $\mathrm{p}$ value of $1.00(>0.05)$, it can be concluded that there is no relationship between work and the success of exclusive breastfeeding. With an OR value of $0.722(0.147-3.545)$ so that the OR value exceeds the value of 1 means that the results of this study apply to the sample only and do not apply to the population.

\section{Discussion}

1) Knowledge

Based on the table, the majority of mother's knowledge is good and
$(83.4 \%)$, there is an effect of mother's knowledge with exclusive breastfeeding. Based on the results of the study, it shows that there is a relationship between knowledge and exclusive breastfeeding in the work area of the Suranenggala Health Center in 2021 with a p value of 0.003 with an OR value of good knowledge against 4.5, which means that well-informed mothers have a 4.5-fold effect on exclusive breastfeeding.

Based on the questionnaire given by the researcher, most of the respondents in the case and control groups did not know the answers to several questions in the questionnaire including questions in numbers 3 and 
18, namely whether colostrum should be removed or the content of colostrum, question number 16 about family support against exclusive breastfeeding, and questions about the benefits of exclusive breastfeeding can be natural contraceptives.

The results of this study support the results of previous research conducted by (Anggraeni, 2016) with the results of the research that there is a relationship between knowledge and work of mothers with exclusive breasfeeding at Posyandu Lestari Handayani, Jembungan Village, Boyolali Regency ( $\mathrm{p}<0.05)$. Another study was also conducted by Rica triseptinora. The Relationship between Knowledge Age and Mother's Occupation with Exclusive Breastfeeding at the Puskesmas Kenali Besar Jambi City in 2018 with a p-value $=0.039(\mathrm{p}$-value <0.05).

Knowledge is the basis for a person to determine or make decisions. Health knowledge can be obtained with formal education and mass media, knowledge about exclusive breastfeeding will raise awareness of a mother to provide exclusive breastfeeding. Knowledge also includes motivation to behave and act. Mothers who are less knowledgeable and less advised about the importance of exclusive breastfeeding will cause them to provide additional food besides breast milk before their time (Rahman, 2017).

\section{2) Mother's Work}

Based on the results of the study, it shows that there is no relationship between work and exclusive breastfeeding in the working area of the Suranenggala Health Center in 2021 with a $\mathrm{p}$ value of $1,000>0.05$. With an OR value of $0.722(0.147$ 3.545) so that the OR value exceeds the value of 1 which means that the results of the study apply to the sample only and do not apply to the population. From the findings of researchers who conducted in-depth interviews with several respondents who work and do not provide exclusive breast feeding, they do not know how to give breast milk when the mother is working and do not know how to store breast milk.

The results of this study are in line with research conducted at the Bungus Health Center, which shows that most mothers do not work, which states that there is no significant 
relationship between work and exclusive breastfeeding with $\mathrm{p}$ value $=$ $0.638>\alpha 0.05$. The study also states that many mothers only take care of household chores and do not exclusively breastfeed their babies. There were 59 mothers and of that number only 22 people (37.3\%) were breastfeeding exclusively, the remaining 37 people $(62.7 \%)$ were mothers who did not exclusively breastfeed. Similar research conducted in Manado stated that there was no relationship between maternal occupation and exclusive breastfeeding $(p$ value $=0.052>\alpha 0.05)$. These results indicate that there are more mothers who do not work than those who work. The study also stated that the majority of mothers who did not work chose not to breastfeed their babies (64\%). While mothers who work and continue to breastfeed their babies 0-6 months are only 13 people (36\%) (Kusmiyati, Adam \& Pakaya, 2014).

Government Regulation No. 33 of 2012 concerning exclusive breastfeeding Article 30 (Workplace and Public Facilities) Paragraphs 1 and 2 state that work agencies and public facilities should provide support for exclusive breast feeding programs and can regulate work relations between companies and employees (Indonesia, 2012). If not, the company or agency will receive criminal sanctions in accordance with Article 200/201 of the Health Law in Article 36 (DepKes, 2009).

\section{Conclusion}

1. In the case and control groups, the majority of mothers were knowledgeable and did not work.

2. Good knowledge has a 4.5 fold effect on the success of exclusive breastfeeding.

3. There is no effect of mother's work on the success of exclusive breastfeeding.

\section{Suggestion}

1. For puskesmas. Increase the activities of providing health education about exclusive breastfeeding to pregnant women in health service activities such as classes for pregnant women, posyandu, and others, so that the coverage of exclusive breast feeding increases.

2. For other researchers. conduct further research with more complete variables and a wider area, in addition to maximizing the total 
sample size in order to achieve the minimum number of samples.

\section{Reference}

Anggraeni, T. 2016. Hubungan Pengetahuan dan Pekerjaan Ibu dengan pemberian ASI eksklusif di Posyandu Lestari Handayani Desa Jembungan Kabupaten Boyolali. Infokes: Jurnal Ilmiah Rekam Medis dan Informatika Kesehatan. 6(1).

Astuti, I. 2013. Determinan pemberian ASI eksklusif pada ibu menyusui. Jurnal Health Quality. 4(1):1-76.

Bahriyah, F., Putri, M. \& Jaelani, A.K. 2017. Hubungan pekerjaan ibu terhadap pemberian asi eksklusif pada bayi di wilayah kerja puskesmas sipayung. Jurnal Endurance: Kajian Ilmiah Problema Kesehatan. 2(2):113118.

DepKes, R.I. 2009. Kebijakan departemen kesehatan tentang peningkatan pemberian air susu ibu (ASI) pekerja wanita. Jakarta: Depkes.

Hilala, A. 2013. Faktor-Faktor Yang Berhubungan Dengan Pemberian Asi Esklusif Di Wilayah Kerja Puskesmas
Tuladenggi Kecamatan Telaga Biru Kabupaten Gorontalo Tahun 2013.

Indonesia, P.R. 2012. Peraturan Pemerintah Republik Indonesia nomor 33 tahun 2012 tentang pemberian air susu ibu eksklusif. Kusmiyati, K., Adam, S. \& Pakaya, S. 2014. Hubungan pengetahuan, pendidikan dan pekerjaan ibu dengan pemberian makanan pendamping ASI (MP-ASI) pada bayi di Puskesmas Bahu Kecamatan Malalayang Kota Manado. JIDAN (Jurnal Ilmiah Bidan). 2(2).

Mufdlilah, M. 2017. Buku Pedoman Pemberdayaan Ibu Menyusui Pada Program Asi Eksklusif. Universitas' Aisyiyah Yogyakarta.

Rahman, N. 2017. Pengetahuan, Sikap, Dan Praktik Pemberian Asi Eksklusif Di Wilayah Kerja Puskesmas Jumpandang Baru Kecamatan Tallo Kota Makassar. Universitas Hasanuddin Makassar.

Triseptinora, R. 2018. Hubungan Umur Pengetahuan dan Pekerjaan Ibu dengan Pemberian Asi Eksklusif di Puskesmas Kenali Besar Kota 
It'S

eMICH $D_{2}$ $1^{\text {st }}$ INTERNATIONAL SEMINAR OF GENDER, MATERNAL, EQUITY AND CHILD HEALTH

DOI: $\underline{10.34305 / g e m i c . v 1 i 1.310}$

Jambi Tahun 2018. Scientia

Journal. 8(1):286608. 